\title{
Selected economic factors impacting tourist travel in Poland between 2000 and 2012 and a forecast for 2013-2017
}

\author{
Pawel Kućmierz, Lukasz Mazurkiewicz, Adam Walanus \\ AGH University of Science and Technology, Faculty of Geology, Geophysics and Environmental Protection, \\ al. Mickiewicza 30, 30-059 Kraków; \\ e-mail:pawel.kucmierz@agh.edu.pl
}

\begin{abstract}
The paper presents an analysis of tourist travel in Poland during the 2000-2012 time period and predictions for years 2013-2017. Since 2000 the amount of travelling Polish citizens has declined. Various factors may have impacted this state of matters e.g. the economic crisis or increasing the VAT rate. The biggest decline in tourist travel was observed between 2007 and 2009 and in 2011. On the other hand, the factor which increased the number of visits between 2007 and 2009 may have been the Euro 2012 championship, organized by both Poland and Ukraine. The paper presents a "eurosensitivity" factor, which describes the increase in people visiting selected voivodeships during 2012, primarily due to the Euro 2012 championship. According to the calculations, the voivodeship which benefited from the highest increase was Matopolska. The article also presents an estimation of travel for years 2013-2017.
\end{abstract}

Key words: tourism travel, trip prediction, economic conditionality, Euro 2012

\section{Introduction}

Tourism is one of the key sectors of the economy, especially in developing countries. Right now, because of numerous changes, it's being subjected to many fluctuations. Tourism is highly dependent on the wealth of citizens, therefore one of the factors of profound impact on the stagnation of both Polish and global tourism has been the economic crisis. During recent years there has been a steady decline in travel among the Polish people. In 2000 the combined number of visits in various voivodeships (province) was 64,1 million whereas in 2011 it was only 30,1 million (Laciak, 2004, 2008, 2012). Further in the article a detailed analysis is presented including the regression of tourist visits of Polish people along with the causes. The decline may be connected with the economic crisis which is considered to has begun in 2008 (Rechela et. al., 2011), although some scientists point to 2007 (Shahrokhi, 2010). Many researchers work on similar topics. The examples include an analysis describing how the decline of tourism affects a country's economy (Steiner et. al., 2013) or a paper pointing to a sharp decrease of global tourist visits in 2009 (Kapiki, 2012). In 2011 the worst result in 12 years in Polish tourism was recorded, 30.1 million visitors which corresponds to about $47 \%$ of the result observed in 2000 . The reason behind this phenomenon may be the increase in the VAT tax. Along with factors that negatively impacted Polish tourism, we can recognize a few key facts which had been beneficial. 2012 was the best year in terms of Polish travel since 2004. In this case the sharp rise in travel may had been due to organization of the biggest sporting event of the old continent - the Euro 2012 championship.

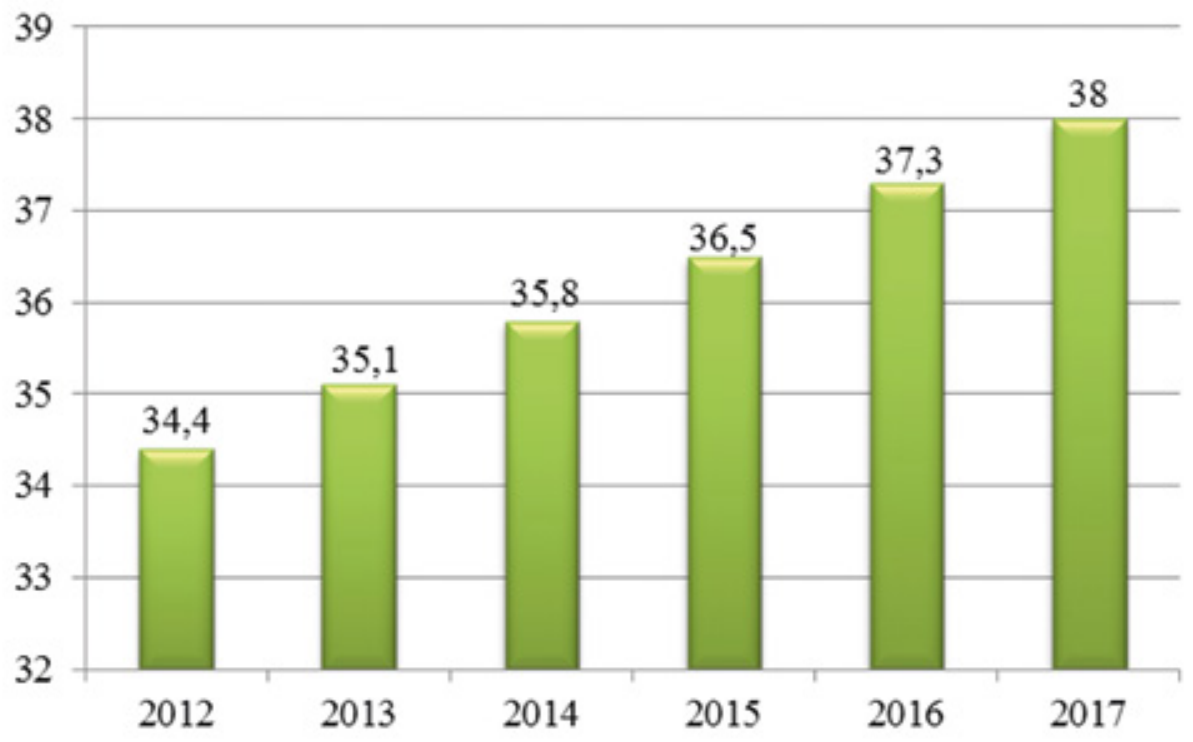

\section{Estimation of internal tourist travel between 2012-2017 in millions}

$\square$ Number of trips (mln)

Fig. 1. Estimation of internal tourist travel between 2012-2017 in millions - see legend in Table 2 (source: http://www.intur.com.pl/images/wykresy/high/podrozepolakow.htm) 


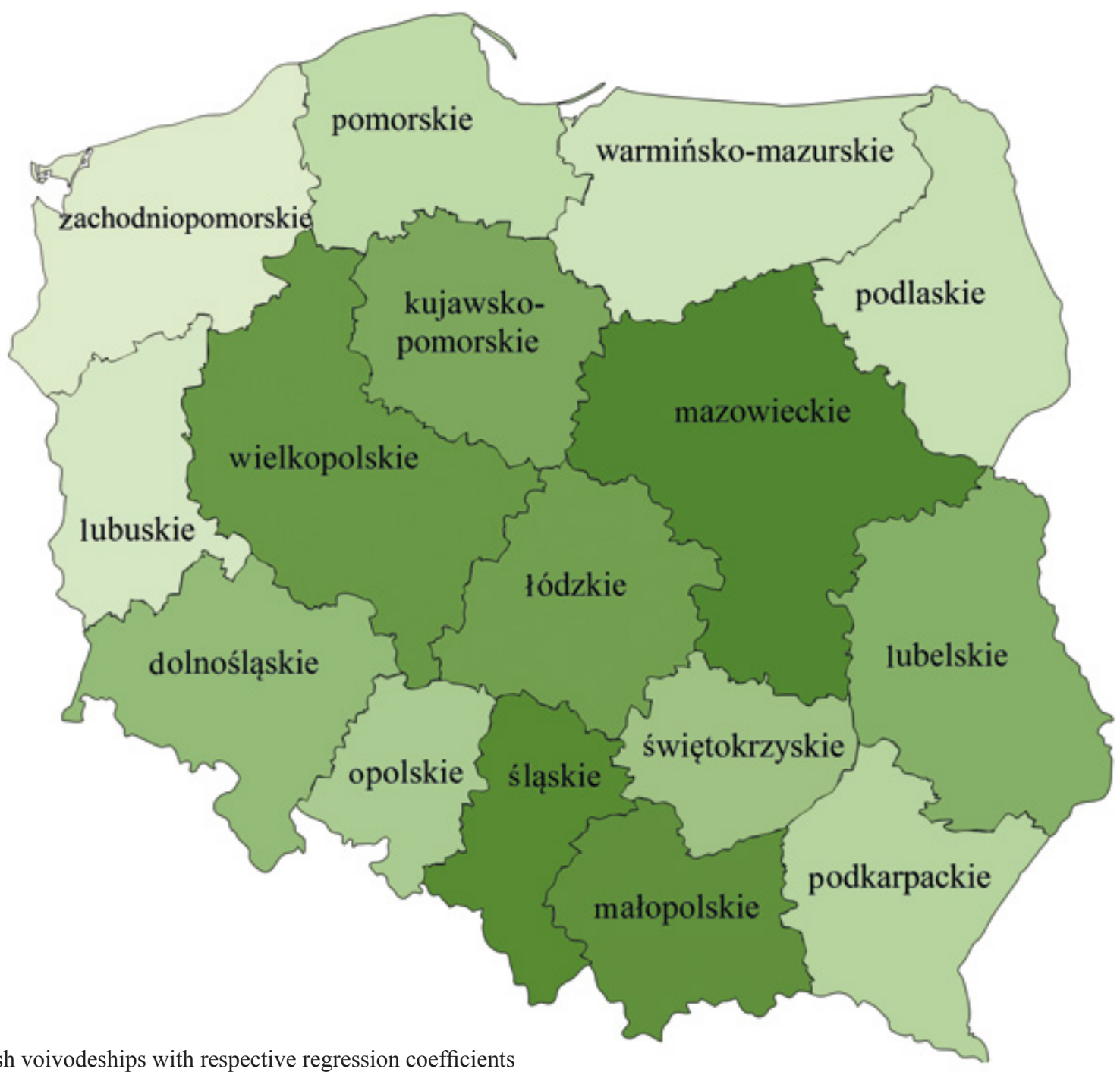

Fig. 2. Polish voivodeships with respective regression coefficients

\section{Research material}

The research was based on data regarding Polish internal tourist travel analyzed between 2000 and 2012 by the Institute of Tourism of the School of Tourism and Recreation in Warsaw. These data depict the number of short-term (from 2 to 4 days) and long-term (5 and more days) visits (each voluntary trip outside the place of residence accompanied by at least one overnight stay) of Polish people categorized into voivodeships, and the overall number of trips (one trip may include many visits) of Polish people in a given year. These data are presented in Table 1. Along with the data, the article uses the estimates created by the Institute of Tourism concerning the combined number of Polish trips for 2012-2017 presented in Figure 1.

\section{Tourist travel data analysis}

Statistical travel and economic factors between 2000 and 2012

The data in Table 1. points to a steady decline in travel since 2000 with the exception of 2010 and 2012, where in compari- son to the previous year, the number of trips had increased by 3.1 million and 11.1 million respectively. The smallest number of trips occurred in 2011 with 29.6. The decline may be interpreted through the economic conditions at the time. In to 2011 the vat tax was increased by 1 percentage point. Even though the increase is relatively small, it caused the raise in product and services costs. It directly influenced a decline in the number of trips, due to that fact that people living on a constant home budget prioritize the essential products and services over tourism. Furthermore Poland is still being subjected to the results of the economic crisis which began in 2008. It had a profound effect on the state of tourist travel observed by analyzing the number of trips between 2007 and 2010.

Further in the article regression coefficients are presented for each voivodeship. These coefficients describe the dependency between the number of visits and time. Figure 2 shows the map of Poland divided into voivodeships along with individual regression coefficient values. The highest absolute value of the coefficient belongs to the Mazowieckie voivodeship (0.468), which means that between 2000 and 2011 the voivodeship was subject to the highest decline in people visiting the region. 
Selected economic factors impacting tourist travel in Poland between 2000 and 2012 and a forecast for 2013-2017

\begin{tabular}{|c|c|c|c|c|c|c|c|c|c|c|c|c|c|}
\hline & 2000 & 2001 & 2002 & 2003 & 2004 & 2005 & 2006 & 2007 & 2008 & 2009 & 2010 & 2011 & 2012 \\
\hline dolnośląskie & 5.2 & 3.5 & 3.9 & 2.8 & 3.1 & 2.9 & 3 & 2.2 & 3.2 & 2.8 & 2.8 & 2.7 & 3.7 \\
\hline kujawsko-pomorskie & 4.1 & 2.7 & 3.1 & 3 & 2.7 & 2.7 & 2.7 & 2 & 2.2 & 1.8 & 1.6 & 1.6 & 2.2 \\
\hline lubelskie & 3.3 & 2.3 & 3.2 & 3.2 & 2 & 1.6 & 2.1 & 1.5 & 2.1 & 1.7 & 1.3 & 1.8 & 1.8 \\
\hline lubuskie & 1.4 & 1.5 & 1.3 & 1.3 & 1.9 & 0.9 & 1.1 & 1.4 & 1.4 & 0.9 & 1 & 0.8 & 1 \\
\hline lódzkie & 4.3 & 2.5 & 2.7 & 1.8 & 1.4 & 1.3 & 1.6 & 1.3 & 0.9 & 1.2 & 1.4 & 1.2 & 1.5 \\
\hline małopolskie & 6.6 & 5.6 & 5.3 & 4.8 & 3.8 & 3.8 & 3.8 & 3.6 & 3 & 2.4 & 2.8 & 2.8 & 5.2 \\
\hline mazowieckie & 9.9 & 6.5 & 7.3 & 6.4 & 5.1 & 5.8 & 5.5 & 4.4 & 4.4 & 3.5 & 3.9 & 3.4 & 5.5 \\
\hline opolskie & 1.4 & 1.8 & 1.6 & 1.2 & 0.8 & 0.4 & 0.7 & 0.6 & 0.6 & 0.7 & 0.5 & 0.4 & 0.5 \\
\hline podkarpackie & 2.4 & 1.7 & 3.1 & 2.7 & 3 & 2.5 & 2.1 & 2.2 & 2.1 & 1.7 & 1.5 & 1.4 & 2.4 \\
\hline podlaskie & 1.1 & 2.8 & 1.9 & 1.9 & 1 & 1 & 1.4 & 1.7 & 0.8 & 0.8 & 1.4 & 1.5 & 0.9 \\
\hline pomorskie & 4.4 & 4.6 & 4 & 4.8 & 3.5 & 3.2 & 3.2 & 3.7 & 3.7 & 3.7 & 4.5 & 2.8 & 5.2 \\
\hline śląskie & 7 & 4.9 & 5 & 4 & 3.6 & 2.8 & 3.1 & 1.9 & 2.4 & 1.8 & 2.6 & 2.5 & 3.3 \\
\hline świętokrzyskie & 2.2 & 2.4 & 2.6 & 1.6 & 1.3 & 1 & 0.9 & 1.1 & 1.1 & 0.9 & 1.3 & 1 & 1.2 \\
\hline warmińsko-mazurskie & 2.4 & 2.6 & 2.6 & 2.6 & 1.9 & 1.6 & 2.1 & 2.4 & 2.1 & 2 & 2.1 & 1.8 & 2.2 \\
\hline wielkopolskie & 4.5 & 4.2 & 3.5 & 3.7 & 3.4 & 3 & 3.2 & 2.1 & 2.4 & 2.4 & 2.4 & 1.6 & 3.1 \\
\hline zachodniopomorskie & 3.9 & 4.2 & 3.5 & 3.6 & 2.6 & 2.4 & 3 & 3.3 & 3.3 & 3.5 & 3.9 & 2.8 & 3.1 \\
\hline Combined number of visits & 64.1 & 53.8 & 54.6 & 49.4 & 41.1 & 36.9 & 39.5 & 35.4 & 35.7 & 31.8 & 35 & 30.1 & 42.8 \\
\hline Combined number of trips & 63.9 & 53.8 & 54.2 & 48.4 & 39.6 & 35.9 & 38.5 & 34.9 & 34.9 & 30.8 & 33.9 & 29.6 & 40.7 \\
\hline
\end{tabular}

Tab. 1. Overall numbers (in millions) of internal Polish travel between 2000 and 2012 by voivodeships (source: Łaciak, 2004, 2008, 2012)

The majority of tourists usually pick Warsaw. On the other end of the classification is the Zachodniopomorskie voivodeship, which is also subject to a steady decline in people traveling, but with a much lower intensity which is represented the linear regression coefficient $0.468 \pm 0.07$. The full classification is presented in Table 2.

Based on the calculated regression coefficients, the prognosis of the numbers of trips was created for the 2012-2017 period. For the total amount of trips, the regression coefficient is $2.794 \pm 0.36$. The prognosis was created based on the statistical data gathered between 2000 and 2011 with the exclusion of 2012.

According to the estimations based on the linear regression coefficient presented on Figure 3. The number of trips in 2012 was between 14 million and 36 million. According to the Institute of Tourism's prognosis, the total number of trips was predicted to amount to about 34.4 million. After gathering the 2012 data, the actual number of trips was 40.7 million which is 4.7 million more than the maximum estimation from the re- gression coefficient, due to the fact of not taking the economic factors into account. Their prognosis shows that during the persisting, decreasing trend the maximum number of trips may fall below 24 million in 2017. According to the Institute of Tourism prognosis, the number of trips in 2017 will amount to about 38 million. The difference in results is probably due to the fact, that the Institute of Tourism takes into account other factors (not only the number of trips), because events which draw large numbers of people from Poland and abroad may have a profound effect on the trend. Raw statistical data does not take this into account. Comparing the prognoses up to 2000 (63.9 million of trips), we observe a decline of about $60 \%$. Analyzing the total amount of visits, the decline is similar, also around $60 \%$.

In the further part of the analysis a prognosis was presented for individual Polish voivodeships. We analyzed and compared the results estimated for 2017 with the results for the year having the maximum number of visits for every voivodeship between 2000-2011 (Table 3). Several voivodeships were chosen for interpretation. 


\begin{tabular}{|c|c|c|c|}
\hline & Voivodeship & Regression coefficient [milion trips per year] & Color on map \\
\hline 1 & zachodniopomorskie & $0.047 \pm 0.05$ & \\
\hline 2 & lubuskie & $-0.051 \pm 0.02$ & \\
\hline 3 & warmińsko-mazurskie & $-0.055 \pm 0.02$ & \\
\hline 4 & podlaskie & $-0.066 \pm 0.05$ & \\
\hline 5 & pomorskie & $-0.089 \pm 0.05$ & \\
\hline 6 & podkarpackie & $-0.099 \pm 0.04$ & \\
\hline 7 & opolskie & $-0.113 \pm 0.02$ & \\
\hline 8 & świętokrzyskie & $-0.134 \pm 0.03$ & \\
\hline 9 & dolnośląskie & $-0.147 \pm 0,04$ & \\
\hline 10 & lubelskie & $-0.149 \pm 0.04$ & \\
\hline 11 & kujawsko-pomorskie & $-0.184 \pm 0.02$ & \\
\hline 12 & łódzkie & $-0.206 \pm 0.05$ & \\
\hline 13 & wielkopolskie & $-0.231 \pm 0.02$ & \\
\hline 14 & małopolskie & $-0.339 \pm 0.04$ & \\
\hline 15 & śląskie & $-0.369 \pm 0.07$ & \\
\hline 16 & mazowieckie & $-0.468 \pm 0.07$ & \\
\hline \multicolumn{2}{|r|}{ Combined number of visits } & $-2.748 \pm 0.35$ & \\
\hline \multicolumn{2}{|r|}{ Combined number of trips } & $-2.794 \pm 0.36$ & \\
\hline
\end{tabular}

Tab. 2. Voivodeships classified by the regression coefficient

In Małopolska the estimated maximum number of visits in 2017 is about 1.5 million. Compared to 2000 (6.6 million) it gives a decline of about $80 \%$. The estimated maximal number of visits in the Śląskie voivodeship in 2017 is about 1.9 million. It is a $70 \%$ decline compare to the year 2000. The aforementioned voivodeships will probably have the highest decline in the number of visits compared to the year 2000 - about $10 \%$ higher than the estimated country-wide decline. The only voivodeship in which, according to estimates, there will be an increase in visits is the zachodniopomorskie voivodeship. The increase is estimated to be around 5\%. Table 4 shows the prognosis for the total number of visits for individual voivodeships in 2014.

The paper also presents a second variation of estimation which takes into account the data between 2007 and 2012. It's an interval between the start of the economic crisis and the date of the Euro Football Championship, in which an increase of tourist travel was observed. Figure 4 presents the total amount of trips made by Polish people taking into account the data from 2007-2012.

Contrary to the previous analysis, the plot shows an increasing trend. The prognosis for 2017 is $14-62$ million trips, with the average at about 38 million. In the prognosis (taking into account the economic crisis), we can tell that the Euro Championship in 2012 will have a profound effect on the number of trips in successive years.

In 2012 Poland and Ukraine were the hosts of the Euro 2012 football championship. It resulted in a sharp increase of tourist travel in Poland. For the purpose of investigating the increase in tourist travel a coefficient was proposed. The coefficient determines which voivodeship gained the most due to the Euro 2012 event. The coefficient is called "eurosensitivity":

$$
E=\frac{3 \cdot N_{2012}}{N_{2009}+N_{2010}+N_{2011}}
$$

$N$ - number of visits during the specific year 


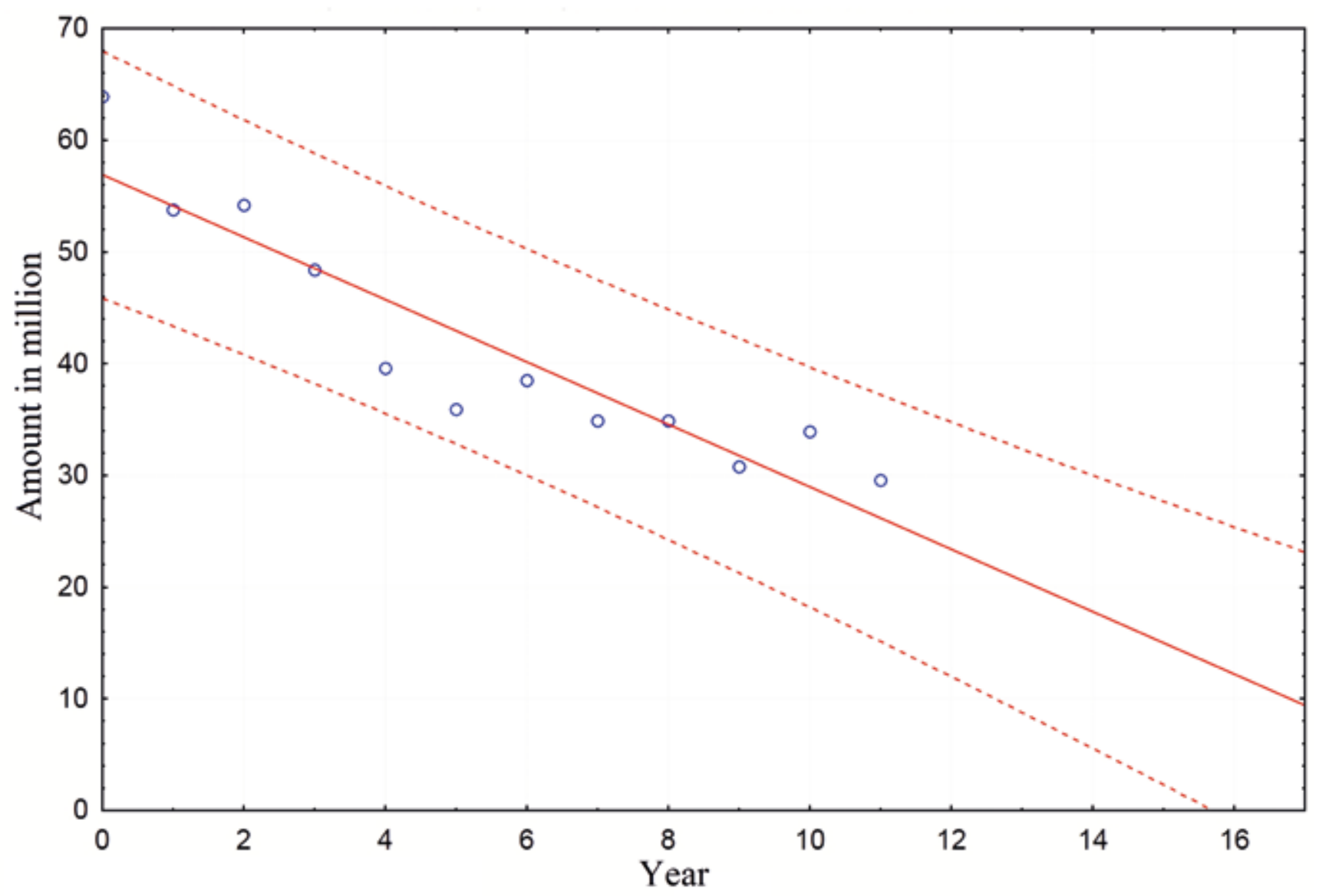

Fig. 3. The regression plot of the amount of trips as a function of time with a $95 \%$ confidence interval

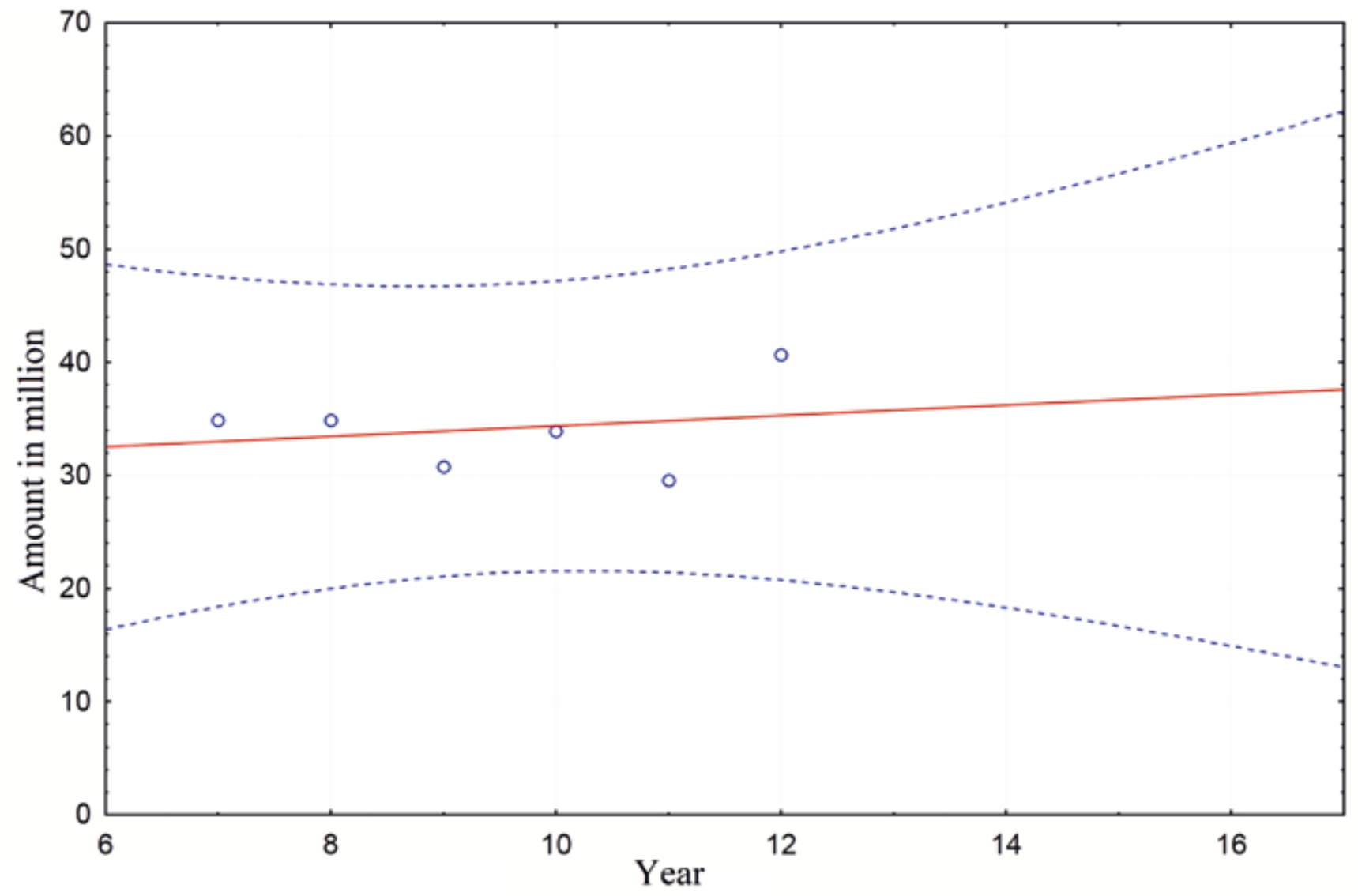

Fig. 4. The regression plot of the amount of trips as a function of time with a 95\% confidence interval for 2007-2017 


\begin{tabular}{|c|c|c|c|c|}
\hline & Voivodeship & Max from 2000-2011 (million) & $\begin{array}{l}\text { 95\% confidence interval prognosis } \\
\text { in } 2017 \text { (million) }\end{array}$ & $\begin{array}{l}\text { Expected value } \\
\text { in } 2017 \text { (million) }\end{array}$ \\
\hline 1 & małopolskie & 6.6 & $0-1.5$ & 0.1 \\
\hline 2 & śląskie & 7 & $0-1.9$ & 0 \\
\hline 3 & opolskie & 1.8 & $0-0.5$ & 0 \\
\hline 4 & wielkopolskie & 4.5 & $0-1.3$ & 0.4 \\
\hline 5 & mazowieckie & 9.9 & $0-3$ & 0.1 \\
\hline 6 & łódzkie & 4.3 & $0-1.4$ & 0 \\
\hline 7 & kujawsko-pomorskie & 4.1 & $0-1.4$ & 0.4 \\
\hline 8 & świętokrzyskie & 2.6 & $0-1.2$ & 0 \\
\hline 9 & lubelskie & 3.3 & $0-1.9$ & 0.5 \\
\hline 10 & dolnośląskie & 5.2 & $0-3.3$ & 1.5 \\
\hline 11 & podkarpackie & 3.1 & $0-2.3$ & 1 \\
\hline 12 & lubuskie & 1.9 & $0-1.5$ & 0.7 \\
\hline 13 & podlaskie & 2.8 & $0-2.5$ & 0.7 \\
\hline 14 & warmińsko-mazurskie & 2.6 & $0.7-2.4$ & 1.6 \\
\hline 15 & pomorskie & 4.8 & $1-4.5$ & 2.9 \\
\hline 16 & zachodniopomorskie & 4.2 & $1-4.4$ & 2.9 \\
\hline
\end{tabular}

Tab. 3. Comparison of prognoses for 2017 with the maximal number of visits for individual voivodeships between 2000-2011

\section{Eurosensitivity}

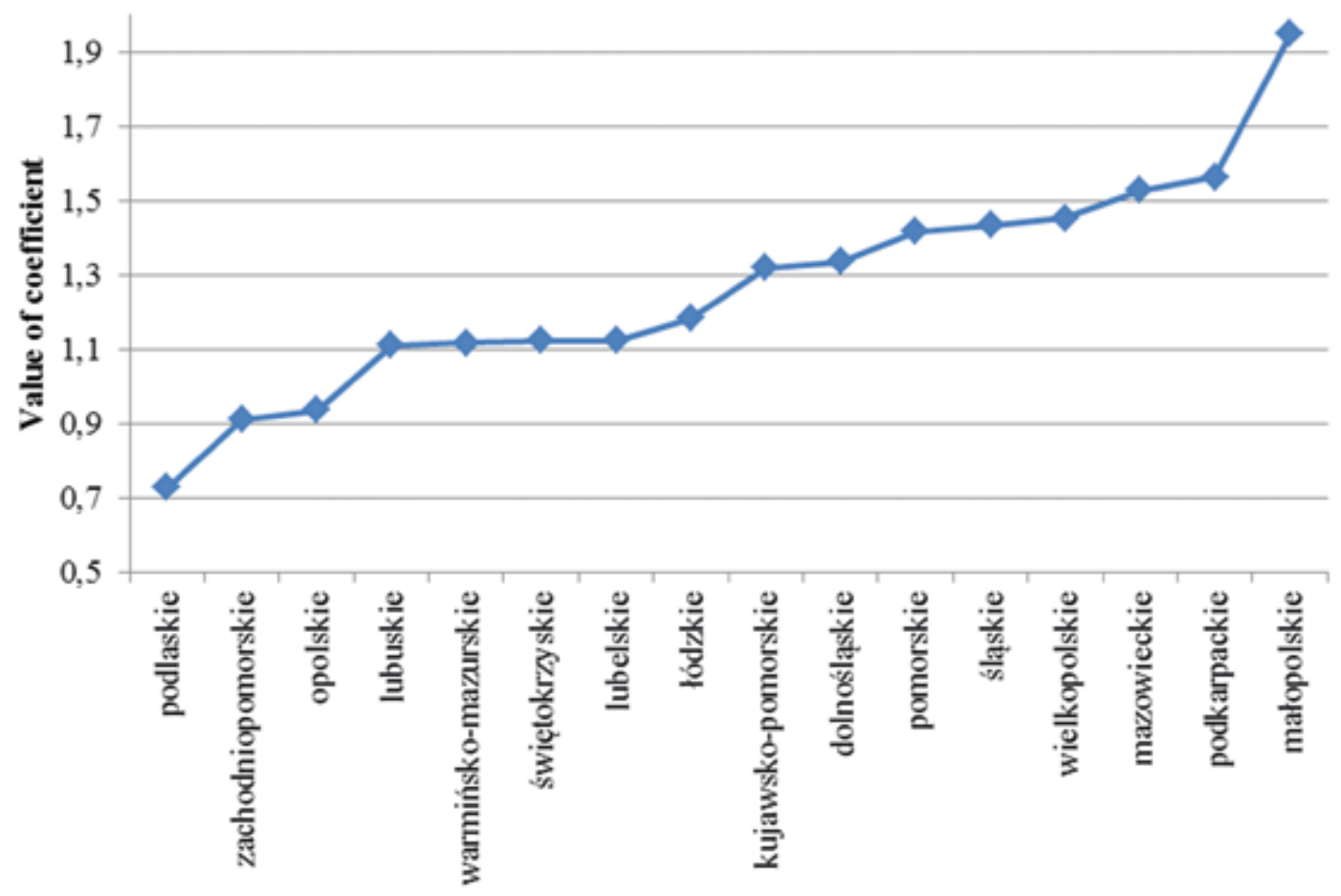

Fig. 5. Eurosensitivity plot 


\begin{tabular}{|c|c|c|c|}
\cline { 2 - 4 } \multicolumn{1}{c|}{} & Voivodeship & $\mathbf{9 5 \%}$ confidence interval prognosis (million) & Average value (million) \\
\hline $\mathbf{1}$ & dolnośląskie & $0.2-3.6$ & 1.9 \\
\hline $\mathbf{3}$ & kujawsko-pomorskie & $0.1-1.8$ & 0.9 \\
\hline $\mathbf{4}$ & lubelskie & $0-2.2$ & 0.9 \\
\hline $\mathbf{5}$ & lubuskie & $0.1-1.5$ & 0.8 \\
\hline $\mathbf{6}$ & lódzkie & $0-1.7$ & 0.1 \\
\hline $\mathbf{7}$ & małopolskie & $0-2.4$ & 1.2 \\
\hline $\mathbf{8}$ & mazowieckie & $0-3.9$ & 1.8 \\
\hline $\mathbf{9}$ & opolskie & $0-0.7$ & 0 \\
\hline $\mathbf{1 0}$ & podkarpackie & $0.1-2.7$ & 1.4 \\
\hline $\mathbf{1 1}$ & podlaskie & $0-2.7$ & 0.9 \\
\hline $\mathbf{1 2}$ & pomorskie & $1.5-4.7$ & 3.1 \\
\hline $\mathbf{1 3}$ & śląskie & $0-2.6$ & 0.3 \\
\hline $\mathbf{1 4}$ & świętokrzyskie & $0-1.4$ & 18 \\
\hline $\mathbf{1 5}$ & warmińsko-mazurskie & $0.9-2.5$ & 1.7 \\
\hline $\mathbf{1 6}$ & wielkopolskie & $0.2-1.9$ & 2.9 \\
\hline & zachodniopomorskie & $1.4-4.5$ & 0.3 \\
\hline
\end{tabular}

Tab. 4. Visit amount prognosis for individual voivodeships in 2014 (million)

The "eurosensitivity" plot (Fig. 5) with voivodeships sorted according to the coefficient indicates the voivodeships which gained the highest number of travelers in 2012.

According to research, the highest increase resulting from the Euro 2012 event was observed in the Małopolskie voivodeship. The result may be interpreted through the location of the training base of 3 national teams taking part in the tournament. Despite the fact that Cracow was not among the cities hosting the championships, it attracted tourists wanting to spectate the 3 high-tier national teams training, free of charge. Furthermore, Cracow is one of the main transport nodes in Poland. Tourists, both from west and north Poland traveling to Ukraine, often picked Cracow as an intermediate station. A significant number of tourists returning from Ukraine took a stop at Cracow, the city of Polish kings, full of wonderful, historical landmarks. Podkarpackie is the second ranked eurosensitivity voivodeship with a result of about 1.5 . The high number is a result of the voivodeship's location. Most tourists going through Ukraine, traveld through podkarpackie. Fur- thermore, the Polish south-east region is rich in tourist atractions, which promote tourism there, for example Bieszczady. The other voivodeships which placed high in the ranking are Mazowieckie, Wielkopolskie, Dolnośląskie and Pomorskie. In each of those Euro 2012 matches took place.

\section{Summary}

The article presents an analysis of tourist travel in Poland between 2000 and 2012 and a prognosis for 20132017. The conducted research indicates a steady decline in travel and visits in Poland. The highest decline was observed from 2007 to 2009 . The decline is probably caused by the effect of the global economic crisis. 2011 is the year with the lowest number of trips. In this case, we can assume that it is the result of the increased VAT tax in Poland. According to the estimated forecasts, the decline will continue reaching below 24 million trips by 2017 . 
The paper also presents the eurosensitivity coefficient which shows the effect of the Euro 2012 on tourist travel in Poland. According to the ranking based on eurosensitivity, małopol- skie and podkarpackie voivodeships gained the most through the Euro 2012 when it comes to the number of tourists.

Rechela B., Suhrckea M., Tsolovab S., Sukb J., Desaic M., McKeec M., Stucklerc D., Abubakara I., Huntera P., Seneka M., Semenza J. 2011. Economic crisis and communicable disease control in Europe: A scoping study among national experts. Health Policy, 103, 2-3: 168-175.

Shahrokhi M. 2010. The Global Financial Crises of 2007-2010 and the future of capitalism. Global Finance Journal: 193-210.

Steiner C., Richter T., Dörry S., Neisen V., Stephenson M., Lemma A., Mitchel J., 2013. Economic Crisis, International Tourism Decline and its Impact on the Poor. World Tourism Organization. 